\title{
Acute limb ischemia secondary to radiation-induced arteritis: case report
}

\author{
Insuficiência arterial aguda secundária a arterite induzida por radiação: relato de caso
}

José Emerson dos Santos Souza', Leonardo Pessoa Cavalcante', Marcos Velludo Bernardes', Marcos Henrique Parisati', Patrícia de Souza Lacerda ${ }^{1}$, Raquel Magalhães Pereira²

\begin{abstract}
Radiation-induced arteritis is a rare but well-known complication of radiotherapy. This report describes the case of a 34-year-old woman with uterine cervical cancer who was diagnosed with left iliofemoral deep vein thrombosis (DVT) 2 years after radiotherapy, and 2 months later, during the treatment of DVT with effective anticoagulation, developed an episode of acute arterial ischemia of the left lower limb secondary to a long subocclusive lesion of the external iliac artery. The patient was treated with angioplasty and stenting of the lesion and recovered uneventfully after the endovascular procedure.
\end{abstract}

Keywords: radiotherapy; constriction, pathologic; angioplasty.

\section{Resumo}

A arterite induzida por radiação é uma rara mas bem documentada complicação da radioterapia. O presente relato descreve o caso de uma mulher de 34 anos, diagnosticada com neoplasia de colo do útero, a qual, dois anos após sessões de radioterapia desenvolveu trombose venosa profunda (TVP) iliofemoral esquerda; dois meses depois, durante tratamento para TVP com devida anticoagulação, a paciente apresentou quadro de insuficiência arterial aguda do membro inferior esquerdo secundária a uma longa lesão suboclusiva da artéria ilíaca externa. A paciente foi tratada com angioplastia transluminal percutânea e implantação de stent autoexpansível, recuperando-se sem intercorrências após o procedimento endovascular.

Palavras-chave: radioterapia; constrição patológica; angioplastia.

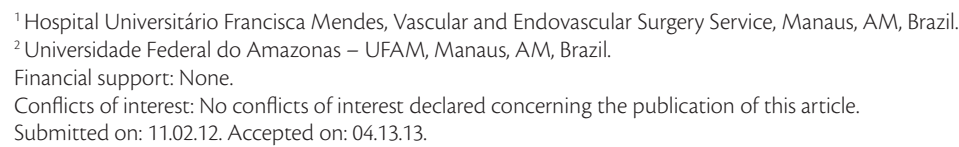




\section{INTRODUCTION}

External-beam radiation for malignancies may cause inflammation and fibrosis in adjacent large arteries and lead to clinically significant stenosis. These lesions are often indistinguishable from atherosclerosis; however, location and confinement to an area previously irradiated indicates that radiation was the cause ${ }^{1,2}$.

The most affected vascular beds are: cervical and cranial arteries, secondary to radiotherapy for esophageal squamous cell carcinoma; visceral arteries, secondary to radiotherapy for lymphoma; and the iliac arteries, secondary to radiotherapy for cervical cancer ${ }^{2,3}$.

The diagnoses is usually made on clinical grounds, and confirmed by noninvasive and invasive test results. This study describes a case of external iliac artery (EIA) radiation-induced subocclusive lesion that led to a rare clinical presentation of acute arterial insufficiency in a patient already on anticoagulation for the treatment of deep vein thrombosis (DVT) of the same limb.

\section{CASE REPORT}

A 34-year-old woman with no risk factors for atherosclerosis was diagnosed with advanced cervical cancer in 2008 and underwent chemotherapy, radiotherapy (57.6 Gy radiation in 32 fractions) and brachytherapy (4 sessions) in the same year.

In June 2011, the patient presented with sudden left lower extremity swelling, calf pain and tightness, but pedal pulses were palpable. A color Doppler ultrasound (US) scan revealed left iliofemoral DVT. She was hospitalized, treated with sequential parenteral and oral anticoagulation (warfarin), and discharged with a stable international normalized ratio (INR) of 2.0 to 3.0.

In August 2011, she returned to the emergency department because of intense pain of the left lower thigh and calf, walking impairment and left foot numbness. Physical examination revealed absence of left femoral, popliteal and pedal pulses and palpable normal pulses in the contralateral limb. The skin temperature on the whole left limb was low, and the left foot was cyanotic. Laboratory tests were normal, except for an INR of 2.3.

The patient was then taken to an endovascular suite and underwent digital angiography, which revealed a long, uniform subocclusive lesion of the left EIA (Figure 1). Filling was delayed in all the distal arteries, but their angiographic appearance was normal.

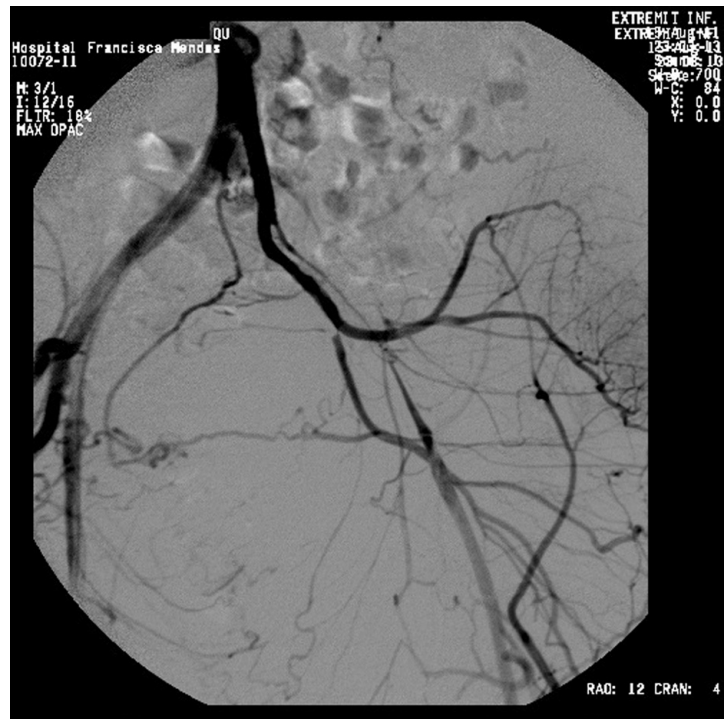

Figure 1. Aortoiliac digital angiography shows left external iliac artery subocclusion.

With the aid of road mapping, the left femoral artery was punctured, and the EIA lesion was easily crossed with a hydrophilic 0.035-in, 180-cm stiff shaft and an angled floppy-tip guide wire; after that, the lesion was pre-dilated using a $6-\mathrm{mm} \times$ 40-mm non-compliant percutaneous transluminal angioplasty (PTA) balloon. Subsequently, 2 selfexpandable nitinol stents were deployed: first, an $8-\mathrm{mm} \times 80-\mathrm{mm}$ stent distally, and then a $9-\mathrm{mm} \times$ $80-\mathrm{mm}$ stent proximally, with an overlapping zone of about $3 \mathrm{~cm}$. For post-dilatation, a $7-\mathrm{mm} \times 80-\mathrm{mm}$ non-compliant PTA balloon was used (Figure 2). Both balloons had to be inflated to nearly their burst pressure to open the lesion adequately. Pressure was measured across the stented region, but no pressure gradient was identified. The completion angiogram showed a satisfactory angiographic result (Figure 3).

On the first post-procedure day, she had normal pedal pulses, and color Doppler US detected normal triphasic flow down to the foot on both left pedal arteries. Clinically, there was remission of the left foot numbness and her left foot movements were preserved. She was discharged from the hospital on the third post-procedure day with a referral for outpatient anticoagulation and INR control.

\section{DISCUSSION}

Radiation-induced stenosis has been described in various organs after radiotherapy for several types of tumors. According to Teixeira et al. ${ }^{4}$, radiationinduced proctitis chronically leading to rectal stenosis is a complication seen in about $1 \%$ to $20 \%$ 


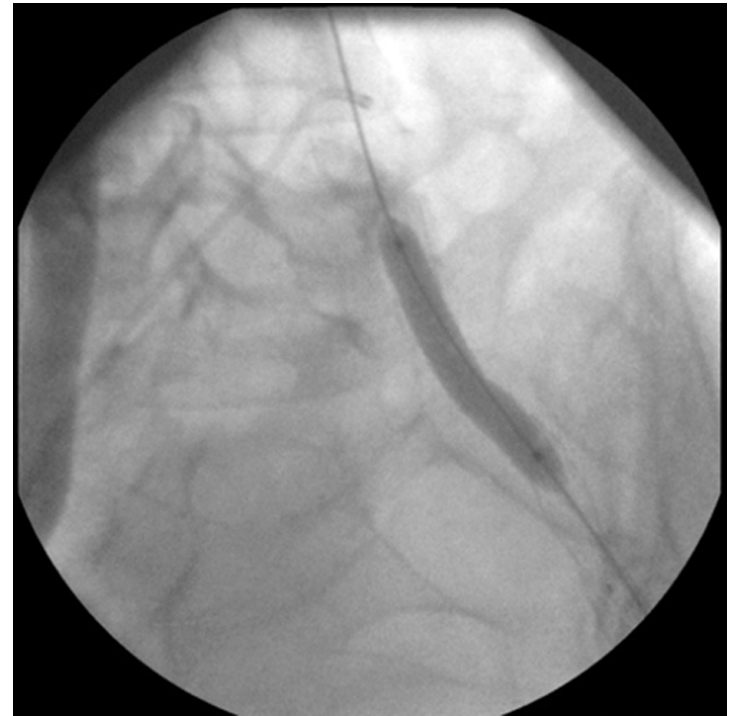

Figure 2. Post-dilatation of two self-expandable nitinol stents with a 7-mm $\times 80-\mathrm{mm}$ non-compliant percutaneous transluminal angioplasty balloon.

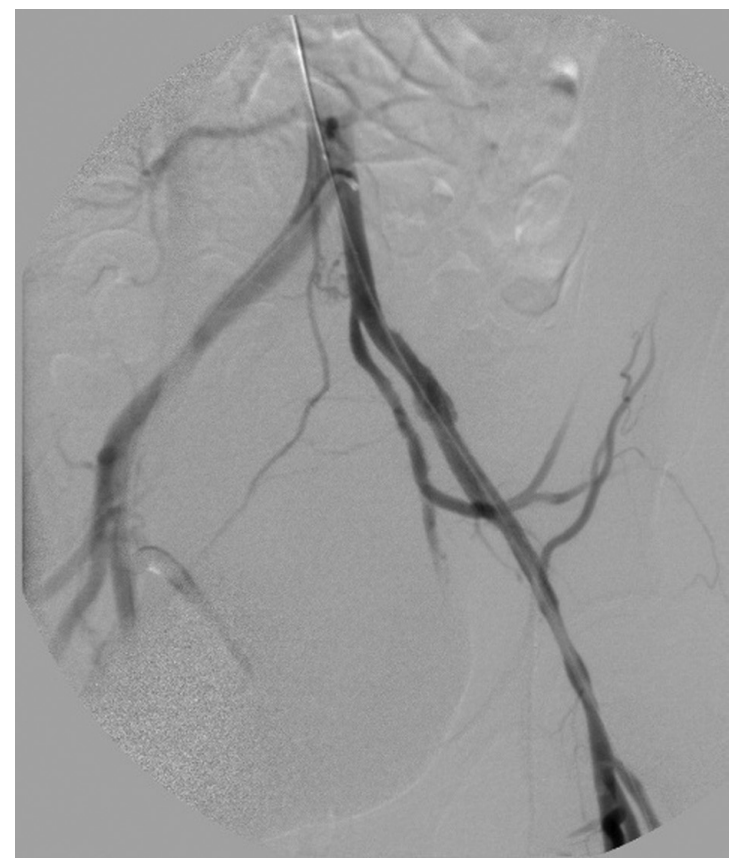

Figure 3. Completion angiogram shows satisfactory angiographic result.

of patients that undergo pelvic region radiotherapy. Novais et al. ${ }^{5}$ found that esophageal radiationinduced stenosis affects $25 \%$ to $67 \%$ of patients irradiated for the treatment of esophageal primary tumors and $1 \%$ to $20 \%$ for the treatment of adjacent tumors (breast, lung, thyroid).

Although still rarely seen in oncology practice, arterial radiation-induced stenosis is becoming more common due to the increased use of radiotherapy and prolonged survival of cancer patients ${ }^{1,6}$. The vessels involved are directly associated with cancer location and the irradiation received.

Arterial occlusive disease pathogenesis begins with direct cellular damage due to radiation or by free radicals produced by its action ${ }^{7}$. Cell damage leads to fibrosis, intimal thickening, elastic middle layer degeneration, adventitia fibrosis and vasa vasorum damage ${ }^{3,6}$. After that, in addition to narrowing, there may be thrombus formation, ulceration and distal embolization ${ }^{1}$.

Although well documented, histological changes are nonspecific and virtually identical to those observed in atherosclerosis ${ }^{1,2}$. Some authors suggest that vasa vasorum injury and the consequent arterial wall ischemia are among the few morphological characteristics that separate radiation-induced lesions from spontaneous atherosclerosis ${ }^{8}$. It has also been suggested that the presence of atherosclerosis risk factors further promotes lesion development after radiotherapy ${ }^{2,6}$. However, the predisposition to atherosclerosis only accelerates vascular injury after irradiation, because the absence of lesions at uninvolved areas indicates that radiotherapy is the primary etiology $\mathrm{y}^{1,2,6}$.

Therefore, the treatment of cervical cancer was the main cause of arterial injury in our patient, as arteriography showed that the disease was restricted to the left EIA, and all the other pelvic and left lower limb vessels had a normal angiographic appearance. Besides that, age and the absence of other atherosclerosis risk factors confirmed the radiation-induced etiology of the arterial disease. The radiation dose reported in the literature to be associated with iliac and femoral artery stenosis is 39.5 to $80 \mathrm{~Gy}^{9}$.

In our patient, acute arterial insufficiency symptoms appeared about 2 years after radiotherapy. In the literature, the time between irradiation and signs and symptoms of damage varies: Piedbois et al. ${ }^{2}$ described a range of 1 to 10 years (mean 6 years); Dorresteijn et al. ${ }^{10}$, reported a mean 13 years; Hassen-Khodja et al. ${ }^{11}$ found a mean 10 years between cervical irradiation and carotid stenosis treatment.

The clinical signs and symptoms of radiationinduced arterial stenosis are not different from other chronic arterial blockages. Therefore, in the arterial involvement of the lower extremities, varying degrees of arterial insufficiency may occur, from exertion muscular ischemia (intermittent claudication) to rest pain and tissue $\operatorname{loss}^{12}$.

Our patient presented with an uncommon clinical picture of acute arterial insufficiency. Although 
she had a chronic arterial lesion that was probably asymptomatic, iliofemoral DVT may have led to an imbalance of the arterial blood supply to the limb, previously compensated through collateral arteries. These arteries may explain why the pulses were palpable during physical examination two months before acute ischemia.

The clinical diagnosis of chronic arterial insufficiency is usually confirmed using color Doppler US and physiological tests (such as ABI) ${ }^{13,14}$. Digital subtraction arteriography is usually reserved for surgical planning ${ }^{1,2,10}$. In the case described here, urgent arteriography was performed after the clinical diagnosis of acute arterial occlusion, and the endovascular treatment was administered at the same time.

Although other treatment options have been described (drug therapy, endarterectomy, extraanatomic bypass) ${ }^{1,2}$, PTA with stent implantation is increasingly becoming the treatment of choice in similar cases because of its low invasiveness and high success rates, as described in the literature ${ }^{12,14}$. PTA associated with stent implantation is extremely effective in the treatment of iliac arterial stenosis of any etiology $y^{14}$. Patients usually have a good postoperative recovery, and clinical improvement is evident, as shown in this case and in the literature ${ }^{12,14}$.

\section{CONCLUSION}

This case demonstrated that PTA with implantation of self-expandable stents is a good therapeutic option for the treatment of radiation-induced EIA stenosis with clinical symptoms in patients treated for advanced pelvic cancer.

\section{REFERENCES}

1. Baerlocher MO, Rajan DK, Douglas J, Rubin BB. Primary stenting of bilateral radiation-induced external iliac stenoses. J Vasc Surg. 2004;40:1028-31. PMid:15557921. http://dx.doi.org/10.1016/j. jvs.2004.08.031

2. Piedbois P, Becquemin JP, Blanc I, et al. Arterial occlusive disease after radiotherapy: a report of fourteen cases. Radiother Oncol. 1990;17:133-40. http://dx.doi.org/10.1016/0167-8140(90)90101-2

3. Warrington KJ, Cooper Jr LT. Vasculitis and Other Arteriopathies. In: Cronenwett JL, Johnston KW, editors. Rutherford's Vascular Surgery. Philadelphia: WB Saunders; 2010. p. 1156-68. http:// dx.doi.org/10.1016/B978-1-4160-5223-4.00076-7

4. Teixeira FV, Pilon B, Marchioni R. Tratamento da retite actínica hemorrágica com o uso de solução de formalina intra-retal: Relato de caso. Rev Bras Coloproct. 2002;22(3):184-9.

5. Novais P, Lemme E, Equi C, Medeiros C, Lopes C, Vargas C. Estenoses benignas de esôfago: abordagem endoscópica com velas de SavaryGilliard. Arq Gastroenterol. 2008;45(4):290-4. PMid:19148356. http://dx.doi.org/10.1590/S0004-28032008000400006

6. Farrugia M, Gowda KMS, Cheatle TR, Ashok TP. RadiotherapyRelated Axillary Artery Occlusive Disease: Percutaneous Transluminal Angioplasty and Stenting. Two Case Reports and Review of the Literature. Cardiovasc Intervent Radiol. 2006;29:1144-7. PMid:16845557. http://dx.doi.org/10.1007/ s00270-005-0230-x

7. Brown KR, Rzucidlo E. Acute and chronic radiation injury. J Vasc Surg. 2011;53(15S):15S-21S. PMid:20843630. http://dx.doi org/10.1016/j.jvs.2010.06.175

8. Zhou W, Bush RL, Lin PH, Lumsden AB. Radiation-associated venous stenosis: Endovascular treatment options. J Vasc Surg. 2004;40(1):179-82. PMid:15218482. http://dx.doi.org/10.1016/j. jvs.2004.03.039

9. Himmel PD, Hassett JM. Radiation-induced chronic arterial injury. Semin Surg Oncol. 1986;2:225-47. http://dx.doi.org/10.1002/ ssu. 2980020405

10. Dorresteijn LDA, Vogels OJM, Leeuw FE, et al. Outcome of carotid artery stenting for radiation-induced stenosis. Int. J. Radiation Oncology Biol. Phys 2010;77(5):1386-90. PMid:20116932. http:// dx.doi.org/10.1016/j.jijrobp.2009.06.045

11. Hassen-Khodja R, Sala F, Declemy S, Lagrange JL, Bouillane PJ, Batt M. Surgical Management of Atherosclerotic Carotid Artery Stenosis after Cervical Radiation Therapy. Ann Vasc Surg. 2000;14(6):608-11. http://dx.doi.org/10.1007/s100169910110

12. Pedron C, Ristow A, Cury JM Fo, Martin HS, Peixoto CC, Fonseca LMB. Tratamento endovascular da oclusão das artérias llíacas. Radiol Bras. 2001;34(5):261-5. http://dx.doi.org/10.1590/ S0100-39842001000500004

13. Donas KP, Schwindt A, Pitoulias GA, Schönefeld T, Basner C, Torsello G. Endovascular treatment of internal iliac artery obstructive disease. J Vasc Surg. 2009;49(6):1447-51. PMid:19497505. http://dx.doi.org/10.1016/j.jvs.2009.02.207

14. Sullivan TM, Childs MB, Bacharach JM, Gray BH, Piedmonte ML. Percutaneous transluminal angioplasty and primary stenting of the iliac arteries in 288 patients. J Vasc Surg. 1997;25(5):829-39. http://dx.doi.org/10.1016/S0741-5214(97)70212-X

Correspondence Leonardo Pessoa Cavalcante Hospital Universitário Francisca Mendes - Serviço de Cirurgia Vascular/Endovascular Av. Camapuã, 108 - Cidade Nova I CEP 69097-720 - Manaus (AM), Brazil E-mail: leonardocavalcante@uol.com.br

Author information

LPC is chief, Endovascular Surgery Service, Hospital Universitário Francisca Mendes MVB is chief, Vascular Surgery Service, Hospital Universitário Francisca Mendes MHP is vascular surgeon, Vascular Surgery Service, Hospital Universitário Francisca Mendes

JESS and PSL are resident physicians (Vascular Surgery), Vascular Surgery Service, Hospital Universitário Francisca Mendes. RMP is medical student, Universidade Federal do Amazonas (UFAM).

Author's contributions Conception and design: JESS, LPC, RMP Analysis and interpretation: MHP, MVB

Data collection: JESS, PSL Writing the article: JESS, LPC, RMP Critical revision of the article: LPC, MVB, MHP Final approval of the article*: JESS, LPC, MVB, MHP, PSL, RMP Statistical analysis: N/A Overall responsibility: JESS Obtained funding: None.

*All authors should have read and approved of the final version of the article submitted to I Vasc Bras. 